\title{
Georg Trakl: um romântico em tempo de guerra
}

\author{
[Geors Trakl: a Romantic in wartime]
}

http://dx.doi.org/10.1590/1982-883718385

\author{
Laura Moosburger $^{1}$
}

\begin{abstract}
This paper seeks to indicate that the presence of the First World War in the poetry of Georg Trakl is inextricably entangled with his dark worldview, in which man is seen as an unavoidably misfortunate being. If on the one hand a romantic longing for purity, beauty, and goodness remains in this poetry, on the other hand such longing is continually refuted by menacing images of the evil inherent in the world - among which the images of the Great War impose themselves perhaps as the most terrifying. In order to show the mentioned connection, we shall first explore the experience of the prevalence of evil in the poem "De Profundis" (De Profundis), written before the outbreak of the War, and secondly we shall analyze that experience in the poems "Grodek" (Grodek) and "Lament" (Klage), in which it is directly related to the War.
\end{abstract}

Keywords: Romanticism; Sehnsucht; war; melancholy.

Resumo: Propomos neste texto indicar que a presença da Primeira Guerra na poesia de Georg Trakl vincula-se de modo inextricável à sua concepção sombria do mundo, em que o homem surge como um ser incontornavelmente desgraçado. Se nessa poesia resiste um romântico desejo de pureza, beleza e bondade, tal aspiração é continuamente refutada por imagens ameaçadoras do mal inerente ao mundo, dentre as quais as da Guerra talvez se imponham como as mais aterradoras. A fim de evidenciar esse vínculo, buscaremos primeiramente explicitar a experiência de prevalecimento do mal no poema "De Profundis" (De Profundis), escrito antes da Guerra, para em seguida analisar essa experiência nos poemas "Grodek" (Grodek) e "Lamento" (Klage), em que está diretamente associada a ela.

Palavras-chave: romantismo; Sehnsucht; guerra; melancolia.

\footnotetext{
${ }^{1}$ Universidade de São Paulo, Faculdade de Filosofia, Letras e Ciências Humanas, Departamento de Filosofia, Av. Prof. Luciano Gualberto, 315, 05508-900, São Paulo, SP, Brasil. Email: laurabmoos@gmail.com. Esta pesquisa está sendo desenvolvida com apoio financeiro da FAPESP.
} 


\section{Trakl, a guerra, o romantismo}

Segundo Pedrag Matvejevitc (1979: 178), o que define a relação de um poeta com uma determinada circunstância, além da natureza e intensidade do acontecimento, é o maior ou menor "grau de implicação pelo qual uma pessoa se encontra entranhada em um acontecimento particular". A intensidade dessa implicação aumenta, mais especificamente, em proporção direta à profundidade subjetiva e pessoal em que ela se dá: à diferença das poesias cerimoniais e daquelas engajadas em termos sóciopolíticos ou históricos, uma poesia de circunstância no sentido da Gelegenheitsgedicht goetheana, qual seja a que canta os fatos "de caráter particular ou subjetivo, fugaz ou mesmo imaginário", "[...] supõe uma possibilidade de participação mais individual, um mais alto grau de implicação" (MATVEJEVITC 1979: 178). É também na experiência subjetiva e em sua expressão que Jean STAROBINSKI (1999: 15) vislumbra o papel do poeta diante de um acontecimento:

[...] a responsabilidade do poeta é antes a de conferir ao evento histórico a qualidade de evento interior, de exprimi-lo na linguagem lírica do sentimento antes que naquela do julgamento e da exortação. Dir-se-ia ainda que o poeta está compelido ao grito, que deve esquecer as palavras e as fórmulas costumeiras, para achar em si mesmo uma palavra nascente, mais próxima do indizível.

É sem dúvida nessa magnitude de envolvimento que se situa o poeta austríaco Georg TRAKL em relação à Primeira Guerra Mundial. Não fosse tão extrema a circunstância por si só, sua experiência pessoal como farmaceuta e enfermeiro militar já teria sido perturbadora o bastante. O episódio mais marcante dessa participação foi em 1914, após a batalha de Grodek (Polônia), quando por dois dias e duas noites se viu sem ajuda de médicos e desprovido de entorpecentes diante dos feridos que lhe imploravam alívio ou até mesmo a morte. Tal experiência de impotência em uma situação de responsabilidade, se não foi a motivação primeira, foi no entanto muito provavelmente o estopim de suas duas tentativas de suicídio (uma delas lograda) ${ }^{3}$. O poema "Grodek", o último de Trakl, escrito logo após a batalha, é um

\footnotetext{
${ }^{2}$ Segundo João BARRENTO (1992: 11), essa sentença proferida por Trakl em diálogo com o escritor Hans Limbach teria sido absorvida de uma personagem de Dostoievski.

${ }^{3}$ Toda biografia de Trakl dá a conhecer uma situação mais ampla que o teria levado ao suicídio. Além de sofrer de esquizofrenia (segundo diagnóstico da época), um momento de grave complicação na vida de sua irmã, com quem mantinha uma relação amorosa, parece tê-lo abalado desmesuradamente, pois antes de testemunhar o 
lacônico e agudo testemunho do peso dessa circunstância, como teremos ocasião de perceber ${ }^{4}$. Há em sua obra mais algumas referências explícitas à guerra, como nos poemas "No Leste" (Im Osten), “A Melancolia" (Die Schwermut) e "Lamento" (Klage), este último escrito no mesmo lapso de tempo que "Grodek": entre o término da batalha e o suicídio. Cabe mencionar que a experiência arrasadora da guerra se soma, no universo histórico de Trakl, à experiência do estilhaçamento do Império Austro-Húngaro - como afirma Modesto CARONE (1974: 18), a poesia de Trakl se torna não apenas uma mimese eficaz, mas também um poderoso testemunho desse universo. As imagens de destruição e decadência em seus poemas dão testemunho de seu tempo histórico, e o tom de constante lamento que as acompanha, como uma marcha fúnebre entoada na sucessão das imagens, dá testemunho do sentimento de horror e desolação com que o poeta contempla o tenebroso cenário. Não poderiam ser mais profundos o entranhamento do poeta na circunstância, a internalização do evento exterior, a “contração do tempo histórico no tempo pessoal” (STAROBINSKI 1999: 10) 5 .

Mas a dimensão dessas experiências para Trakl pode ser compreendida de modo mais profundo ao considerar-se a sua filiação, no âmbito da história do espírito, ao romantismo. Isso permite compreender melhor a sua concepção do mal como inerente à existência - pois ela é indissociável da crise interior na visão romântica do mundo que é experimentada e desenvolvida pelo poeta -, bem como o impacto da Guerra sobre sua sensibilidade, essencialmente romântica. Assim, mais do que a circunstância imediata da Guerra e do esfacelamento do Império Austro-Húngaro, é toda uma configuração histórico-espiritual uma circunstância, por assim dizer, essencialmente interior - que pesa na poesia de Trakl.

Os românticos, em seu desejo e nostalgia (Sehnsucht) do infinito e absoluto, em sua busca de um reencontro com a 'unidade perdida' entre homem e natureza - Deus em um sentido cristão panteísta ${ }^{6}$-, tinham em certa medida o respaldo de uma esperança quanto à possibilidade desse reencontro, uma vez que justamente acreditavam em uma unidade

sofrimento dos feridos na Guerra, Trakl confidenciara o seu próprio em carta ao amigo Ludwig von Ficker: "Nos últimos dias ocorreram-me coisas tão terríveis que durante toda a minha vida não poderei livrar-me delas... É uma desgraça sem par quando o mundo se rompe diante de alguém. Oh, meu Deus, a que tribunal fui submetido! Diga-me que ainda devo ter forças para viver e fazer o que o valha. Diga-me que não estou enganado... Como tornei-me pequeno e infeliz!” (apud CAVALCANTI 2010: 95).

${ }^{4}$ As traduções provisórias de todos os poemas aqui apresentados e interpretados são nossas. Para cotejo, foram utilizadas as versões argentinas de Aldo Pellegrini e as brasileiras de Claudia Cavalcanti, bem como, sempre que possível, as portuguesas de João Barrento e de Paulo Quintela. Para consulta aos originais foi utilizada a historisch-kritische Ausgabe preparada por Walter Killy e Hans Szklenar.

${ }^{5}$ Starobinski glosa Pierre Jean Jouve a respeito de Rimbaud; a referência da frase a Trakl é por nossa conta.

${ }^{6}$ Como tudo no romantismo, seu sentimento religioso do mundo assume feições próprias, unindo de modo único cristianismo, panteísmo, mitologia e romantismo. Em pesquisa mais ampla exploramos o caráter próprio dessa religiosidade; aqui, basta ter em mente que nela domina a ideia de uma correspondência entre a alma e desejos do sujeito humano e o próprio universo, sendo este perpassado por uma 'alma do mundo' (Weltseele).

Pandaemonium, São Paulo, v. 18, n. 25, Jun. /2015, p. 18-36. 
cósmica primordial e, logo, em uma conspiração entre o universo, todos os seres e o homem conspiração cujo momento apoteótico seria uma verdadeira unio mystica, a qual poderia realizar-se ao menos esteticamente. É nesse horizonte que surge a flor azul de Novalis, tornada símbolo do idealismo romântico ao consubstanciar o espiritual e o sensível, o infinito e o finito: vislumbrada em sonhos pelo herói homônimo no romance Heinrich von Ofterdingen, a flor se torna seu ideal máximo, imagem de sua nostalgia infinita, e ele se lança em sua busca. E, embora a flor não possa ser encontrada na realidade do dia, ao menos se realiza no sonho, poeticamente. Ao perguntar-se nos Hinos à Noite, receoso, se "a manhã sempre terá de voltar?", se “jamais terminará o poder da Terra?", "se jamais ficará a arder sem fim a secreta oferenda do amor?", uma vez que a "agitação nefasta [do dia] consome o celeste pousar das Asas da Noite", é o próprio Novalis quem responde afirmando a “perenidade do Sono" para aqueles "que se consagram à Noite” (Novalis 1998: 23). Tal é o sentimento de um prevalecer do poético sonho sobre a realidade prosaica do dia: "o poético é o autêntico real absoluto. Quanto mais poético, mais verdadeiro. É esse o cerne da minha filosofia" (NovALIS apud SANTOS 1947).

O homem do início do século XX já não se sente enlevado por uma correspondência entre seus anseios e o universo: é um homem “órfão de Deus", que já não idealiza a si mesmo, a natureza, o mundo; um homem que, confrontando seus anseios com provações potentes dentre as quais a Grande Guerra -, sente o apelo de uma tomada de consciência menos romântica sobre si próprio e o mundo. Um homem para quem a "flor azul" se revela símbolo apenas de seus desejos, e não imagem de uma realização possível - ainda que só esteticamente - desses desejos. Para a sensibilidade romântica de Trakl, é todo um mundo que se desfaz: o seu é um mundo da decadência e do desterro. Se ele "soube muito bem canalizar as forças de antecessores como Novalis e Hölderlin para a tentativa de refletir poeticamente as dores e os anseios do homem moderno" (SELIGMANN-SILVA 2011), tais anseios não podem mais ser nutridos: para o romântico tardio, resta apenas o sonho desfeito, e nenhuma forma de realização possível. Assim, o que no desejo nostálgico (Sehnsucht) pelo absoluto era, no romantismo, esperança em relação ao futuro, torna-se agora pura melancolia: lamento pela esperança passada e perdida, sem que se tenha perdido o desejo. Assim se tinge toda sua poesia de uma monotônica desesperança, como no poema "Rondel" (Rondel): 
Verflossen ist das Gold der Tage,

Des Abends braun und blaue Farben:

Des Hirten sanfte Flöten starben

Des Abends blau und braune Farben

Verflossen ist das Gold der Tage.
O dourado dos dias se foi,

Cor azul e marrom da tarde:

Já não soa a doce flauta do pastor

Cor azul e marrom da tarde

O dourado dos dias se foi.

(TRAKL 1973: 14)

A imagem nostálgica e romantizante do pastor que tocava a flauta docemente, como que em consonância com o dourado dos dias, intercala-se à imagem sombria e esmorecida da "cor marrom e azul da tarde", gerando um efeito intensificador, como se essa oscilação marcasse o contraste entre a vitalidade dourada do passado e a atmosfera de ocaso que se abate sobre o presente - como talvez se a memória desse passado desejasse tristemente reaparecer na vibração do presente, no lusco-fusco do entardecer. A flauta do pastor não soa mais porque, em sua suavidade, tocava em harmonia com a luz dourada e gentil, que se foi. O sujeito lírico não pode mais se sentir no estado de espírito leve de um pastor que canta com o dia.

Em mais explícita referência ao romantismo, é também significativo o poema de Trakl “A Novalis" (segunda versão) - que, como aponta CAVALCANTI (2010: 97), mais parece um epitáfio de si mesmo:

In dunkler Erde ruht der heilige Fremdling.

Es nahm von sanftem Munde ihm die Klage der

[Gott,

Da er in seiner Blüte hinsank.

Eine blaue Blume

Fortlebt sein Lied im nächtlichen Haus der

[Schmerzen.
Em terra escura repousa o estrangeiro santo.

Dos lábios suaves Deus tomou-lhe o lamento

Quando, florindo, fenesceu.

Uma flor azul

Prossegue seu canto na morada noturna da dor.

(TRAKL 1973: 183)

Novalis é aqui de fato o próprio Trakl: o estrangeiro romântico em um mundo destruído, que, por desejar ainda a flor azul, prossegue no embalo de seu canto; mas se para Novalis a flor azul simbolizava a ansiada unio mystica do homem com a natureza, realizável na Noite, no Sonho, refúgio eterno contraposto à realidade do dia, para Trakl ela simboliza apenas o desejo desenganado, e em última instância nem mesmo a Noite a acolhe: se seu canto prossegue na noite, nela só mora enquanto dor. Como conclui CAVALCANTI (2010: 97), no poema de Trakl o “desejo (sonho) é destruído pela realidade". Poder-se-ia dizer que o poema de Trakl a 
Novalis exprime um diálogo interno de um mesmo espírito que se volta para si próprio no transcorrer de uma crise histórica; Novalis e Trakl, dois momentos de um mesmo espírito: aquele a esperança, este a frustração.

Tão estrangeiro nesse mundo é o eu lírico trakliano, que experimenta sua existência como uma "remota sombra de lugarejos escuros", que "bebeu o silêncio de Deus na fonte do bosque" (do poema "De Profundis", citado e traduzido na íntegra mais à frente). Não se trata apenas de inexistência, mas da ausência de Deus, no lugar do que um dia foi a aspiração e esperança de Sua existência (Deus não está ausente porque um dia existiu, mas porque um dia o homem O sentiu existir). No romantismo agônico de Trakl, não pode haver um reencontro com o absoluto, simplesmente porque nunca houve uma unidade primordial; como exprime BARRENTO (1992: 11) com exatidão, em Trakl o que há é uma disiunctio mystica.

Nessa atmosfera, sua poesia configura-se como descrição de um cenário crepuscular quase imutável, em que vibra a queda, a decadência, a desesperança e a perda. Seu sentimento do mundo se condensa na revelação nítida e insistente desse cenário onde as figuras da pureza e da beleza - "o estranho", "o desconhecido", "o apartado", o adolescente Helian, por fim o próprio poeta que é testemunho de todas essas figuras - encontram-se ora desamparadas pela indiferença do mundo, ora maculadas por sua corrupção. A aspiração à pureza que, como indica Aldo Pellegrini (2009: 10), constitui o próprio elemento poético em Trakl, se vê em constante luta contra a tendência predominante do mundo, a corrupção:

\footnotetext{
A poesia de Trakl poderia resumir o sentido exemplar de toda poesia, se é o fim de toda poesia incitar-nos a recuperar esse mundo ideal a que aspira o homem, e se é a um só tempo denúncia e recusa do mundo falso, inautêntico que se nos oferece. Constituiria o poético, portanto, uma aspiração à pureza. Sua ação se desenrola na esfera do espiritual e se encontra em luta permanente contra a ameaça de corrupção que, começando pelo mundo espiritual, termina por invadir o material.
}

Assim, seus versos descrevem um angustiado e fatídico avanço do impuro sobre o puro, do abjeto sobre o belo, da treva sobre a luz: "À noite encontrei-me num pântano,/ Coberto de lixo e pó de estrelas./ Na avelãzeira/ Soaram de novo anjos cristalinos." (de "De Profundis"), "De quartos cinzentos saem anjos com asas sujas de excrementos" (de "Salmo", TRAKL 2010: 25), "Quando a alma de Helian contempla-se no espelho rosado/ E neve e lepra descem de sua fronte" (de "Helian", TrAKL 2010: 37). Seus poemas, talvez sem exceção, cantam a dor da impossibilidade de o puro e o belo prevalecerem, e mesmo naqueles versos em que não há, aparentemente, traços de corrupção, é num tom de glacial tristeza que brilha o puro: "Pombas 
azuis/ bebem de noite o suor gelado/ que corre da fronte cristalina de Élis" (de "Élis", TRAKL 2009: 133).

A prova mais cabal dessa absoluta disjunção e avanço do mal talvez seja a guerra, impassível de redenção: "Todos os caminhos desembocam em negra putrefação", lamenta o poeta em "Grodek" (também citado e traduzido na íntegra mais à frente). No que segue, ao analisar os poemas "De Profundis", escrito antes da guerra, e "Lamento" e "Grodek", escritos logo após a batalha de Grodek, buscaremos justamente explorar a relação entre o predomínio do mal, que permeia toda a lírica trakliana, e a guerra como evento que tanto confirma quanto alimenta a ideia desse predomínio.

\section{Uma leitura de "De Profundis", "Grodek" e "Lamento"}

\section{DE PROFUNDIS}

Es ist ein Stoppelfeld, in das ein schwarzer Regen fällt.

Es ist ein brauner Baum, der einsam dasteht.

Es ist ein Zischelwind, der leere Hütten umkreist.

Wie traurig dieser Abend.

Am Weiler vorbei

Sammelt die sanfte Waise noch spärliche Ähren ein. Ihre Augen weiden rund und goldig in der

[Dämmerung,

Und ihr Schoß harrt des himmlischen Bräutigams.

Bei der Heimkehr

Fanden die Hirten den süßen Leib

Verwest im Dornenbusch.

Ein Schatten bin ich ferne finsteren Dörfern.

Gottes Schweigen

Trank ich aus dem Brunnen des Hains.

Auf meine Stirne tritt kaltes Metall.

Spinnen suchen mein Herz.

Es ist ein Licht, das in meinem Mund erlöscht.

Nachts fand ich mich auf einer Heide,

Starrend von Unrat und Staub der Sterne.

Im Haselgebüsch

Klangen wieder kristallne Engel.

(TRAKL 1973: 27)

\section{DE PROFUNDIS}

Há um restolhal, onde cai uma chuva negra.

Há uma árvore marrom, que se ergue ali solitária.

Há um vento sibilante, que rodeia cabanas vazias.

Como é triste esse entardecer.

Passando pela aldeia

A terna órfã recolhe ainda raras espigas.

Seus grandes olhos dourados se demoram no [crepúsculo,

E o seu regaço espera pelo noivo divino.

No regresso à casa

Os pastores acharam o doce corpo

Apodrecido no espinheiro.

Uma sombra remota eu sou de lugarejos escuros. O silêncio de Deus

Bebi na fonte do bosque.

Em minha fronte avança um frio metal.

Aranhas procuram meu coração.

Há uma luz, que se apaga na minha boca.

À noite encontrei-me num pântano,

Coberto de lixo e pó de estrelas.

Na avelãzeira

Soaram de novo anjos cristalinos. 
Como é característico na lírica de Trakl, o próprio mundo e a natureza são aqui carregados de tonalidades afetivas. Na primeira estrofe, as imagens do restolhal, da chuva negra, da árvore solitária, do vento sibilante rodeando cabanas vazias, vão compondo um cenário desolado no qual não há vestígio dos homens - senão pelas cabanas que, todavia, estão desabitadas. O sequenciamento dessas imagens vai ampliando o cenário rumo a um efeito de imensidão na qual a subjetividade solitária do eu lírico é absorvida: é a própria tarde que é triste, e ela é tão triste porque sua tristeza é ubíqua, sincronicamente paira pelo restolhal, se precipita como chuva negra, se erige na árvore solitária, volteia no vento sibilante em torno às cabanas vazias, e assim, imensa, pesa sobre o sujeito. Em certo sentido, eu lírico e mundo exterior compartilham uma mesma subjetividade, na qual porém o peso do mundo exterior se sobrepõe e oprime o eu interior. Esse peso também é sugerido pela construção repetitiva das "orações sem sujeito" nos três primeiros versos: Es ist ein Stoppelfeld..., Es ist ein brauner Baum..., Es ist ein Zischelwind... - Há um restolhal..., Há uma árvore..., Há um vento... Essa construção - na qual se pode identificar uma influência de RIMBAUD em seu uso sequencial da forma "Il ya a..." na parte III do poema "Enfance" (1892: 15) - gera uma ênfase que confere aos elementos enumerados uma carga existencial intensificada, e certa estaticidade, como se se tratasse de um estado de coisas pairando estático no tempo, como uma cena antiga, imemorial, existindo desde e para toda a eternidade: Es ist... lembra um pouco o Es war einmal..., nosso "Era uma vez...", com que se iniciam as fábulas. Só que aqui o estado de coisas se encontra no tempo presente, aumentando ainda mais a sensação de eternidade.

Na segunda estrofe, a imagem da aldeia reforça a sensação de um mundo primitivo. A presença humana, por sua vez, não torna o cenário menos hostil, mas sim se soma a ele, pois introduz uma história triste. As cabanas e a aldeia trazem ainda um tom de singeleza, que irá se concentrar na figura da "terna órfâ" que "colhe as raras espigas" e, na sua inocência e sinceridade de ser, reflete o crepúsculo em seus "grandes olhos dourados". O eu lírico de certa forma se aproxima da órfã ao descrevê-la com empatia. E ela, figura do mundo exterior, também se funde ao mundo em sua subjetividade, na medida em que reflete em seus olhos o crepúsculo. Poder-se-ia quase pensar aqui na união mística com a natureza, não fosse o crepúsculo, além de dourado nos olhos da menina, também um presságio de decadência, a qual se cumpre na estrofe seguinte, quando "o doce corpo" é encontrado "apodrecido no espinheiro". É um movimento de queda que se realiza na sequência entre essas duas estrofes: primeiro, a imagem da pureza, que quase encontra misticamente a natureza - os olhos dourados que sorvem e refletem o crepúsculo -, mas esse encontro se revela um desencontro, uma disiunctio mystica, porquanto o crepúsculo prenuncia o mal (prenúncio talvez já Pandaemonium, São Paulo, v. 18, n. 25, Jun. /2015, p. 18-36. 
introduzido na atmosfera lúgubre da primeira estrofe...), e, por fim, a imagem da consumação do mal, que destroça a pureza. Repletas de significância são as imagens da orfandade e do "noivo divino". Elas ajudam a compor a figura inocente e casta da menina, mas seu sentido vai mais longe. O "noivo divino" se refere aqui muito provavelmente a Cristo, o qual é assim denominado no Novo Testamento (HAMMER 2006: 334). O regaço da jovem, tal como o da Virgem Maria, aguarda o casamento sagrado. Mas o noivo divino, Cristo, não vem; em vez disso, o corpo é encontrado em putrefação pelos pastores - aqueles que velam. Por quê? Talvez sua orfandade o explique. Esta poderia ser apenas mais um elemento a sugerir a singeleza, humildade e inocência da menina, mas também pode ser uma referência ao abandono de Deus: é de Deus que ela é órfã. Nesse sentido, a "terna órfã" representa a aspiração a Deus e à fusão do homem terreno e mortal com a divindade dos céus, mas, sendo órfã de Deus, é reduzida à mera condição de corpo, abandonada à morte e à decomposição. Tudo parece desenrolar-se em uma lentidão malévola que ressalta o caráter inevitável dos acontecimentos, como em uma fábula mesmo, em que o destino dos personagens está selado desde o princípio. Ou como na própria Bíblia, em que esse destino é selado pela vontade divina.

Entre a terceira e a quarta estrofes pode-se sentir uma pausa maior, um silêncio mais alongado do que entre as anteriores, na medida em que a quarta estrofe opera uma quebra na narrativa ao referir-se o eu lírico a si mesmo, mas, sobretudo, pelo impacto destas duas sentenças que soam como o ponto central, o coração de todo o poema: "Uma sombra remota eu sou de lugarejos escuros./ O silêncio de Deus/ Bebi na fonte do bosque.” Fala aqui a voz de um testemunho, triste e sombrio, porque bebeu na fonte o abandono, o silêncio de Deus que, ao abster-se diante do mal, como que Ele próprio o consente. O eu lírico sabe desse silêncio como quem provou do fruto do conhecimento. Mas "comer um fruto" não geraria aqui o efeito melancólico e frio da imagem de Trakl: beber é um ato mais imediato, pois não há mediação entre o líquido e sua absorção; e é gelado e obscuro, pois é da fonte do bosque. Tem-se mesmo a arrepiante sensação de uma "remota sombra de lugarejos escuros", que vagueia pelas profundezas do bosque e conhece as trevas que Deus não habita. A quebra dessa estrofe em relação às anteriores, na realidade, revela uma ligação direta: pois a testemunha que conhece profundamente a essência obscura da existência, abandonada ao silêncio/ausência de Deus, é por isso mesmo também testemunha da história narrada, vê e entende seu sentido, que é o sentido de uma história sem Deus. A imagem da "sombra remota" é rica de significado nesse horizonte. Enquanto sombra, ele pode vagar pelo ambiente descrito no poema, o que retrospectivamente confirma a sensação, na primeira estrofe, de uma 
consciência flutuante, acompanhando a atmosfera do restolhal, da chuva, do vento... Pode pairar pelo cenário em que se desenrola a história da órfã. Mas o que significa ser esse testemunho, e sê-lo enquanto sombra? Trata-se de um testemunho ao mesmo tempo profundamente sentido - vem das distâncias remotas de lugarejos escuros, das profundezas do bosque - e completamente impotente. Ao beber o silêncio de Deus, essa sombra conheceu o abandono e a impotência. Uma sombra não é apenas escuridão, ela é o rastro sem luz de algo iluminado e ontologicamente superior. Ser uma sombra é ser a falta desse algo. Tivesse ele luz, talvez pudesse salvar a menina. Mas sombras apenas seguem, nada mudam: assim, ele acompanha a história do início ao fim e, como mera sombra, não pode salvar aquela a quem vê com empatia e ternura. A estrofe seguinte prossegue com a caracterização dessa condição do eu lírico.

"Em minha fronte avança um frio metal./ Aranhas procuram meu coração./ Há uma luz, que se apaga na minha boca." Nos dois primeiros versos, o mal o cerca e invade. A luz é impotente diante desse mal, e se apaga em sua boca: ele não pode dizer o bem. É significativo que a conclusão dessa estrofe retome a estrutura da primeira, com uma oração sem sujeito: "Há uma luz, que se apaga na minha boca". Existe uma luz. Mas ela se apaga na minha boca. Essa luz mais não é que um impotente desejo de luz, refutado pela realidade, e portanto não pode ser proferida de modo a iluminar. Aquele que bebeu o silêncio de Deus não pode mais conter em si a luz. Não se trata apenas de escuridão, mas de uma escuridão enquanto rastro da falta da luz: enquanto sombra. A voz que fala é a voz dessa sombra, que conta a história que nunca pôde evitar. Em certo sentido, essa voz também se revela como a do próprio mal, uma vez que, invadido por ele, o eu lírico se torna obrigatoriamente seu intermédio.

Na última estrofe, é retomada a narrativa linear: "À noite..." quer dizer "esta noite", a que se segue ao triste entardecer no qual se desenrolou a história. A absorção do eu lírico naquele entardecer e no que nele se deu fica novamente reforçada nestas palavras que soam como uma conclusão: “À noite encontrei-me num pântano/ Coberto de lixo e pó de estrelas." O sujeito que não pôde salvar a inocente, e que já confessou sua impotência simultaneamente uma culpa - tem como destino o pântano. Assim como pronunciara o mal ao "apagar-se a luz de sua boca”, aqui o sujeito lírico se iguala ao lixo de que está coberto; como observa Gunther KLEEFELD (1985: 256), ao lado dos diversos objetos feios no imaginário de Trakl também surge um eu feio. Mas essa feiúra do eu não é voluntária, ela é antes algo do qual o sujeito não pode escapar, algo que o cerca, invade e adentra, como o "frio metal que avança em sua testa" e as "aranhas que procuram seu coração". Esse elemento talvez mais 
propriamente expressionista em Trakl, o feio, só ganha sentido na referência ao elemento romântico, aquele do sujeito que deseja a beleza, o bem, a salvação, mas lhe é vedado o direito a isso ${ }^{7}$. Assim, justamente, além de lixo o eu está coberto de pó de estrelas, uma imagem sublime que convive tensamente com o pântano e o lixo. Trakl opera aqui aquela junção de elementos da pureza e beleza com elementos da decadência. Nessa junção se destaca tanto a sensação de um avanço da decadência sobre o puro e belo, quanto a persistência de algo sagrado, que justamente confere à presença do mal em Trakl uma força tão angustiante. Assim, "Na avelãzeira/ soaram de novo anjos cristalinos." A imagem dos "anjos cristalinos" coroa essa angústia, porque sugere a indiferença ou até assentimento por parte dos anjos diante do mal: de modo semelhante ao Deus que permite o mal ao silenciar-se, os anjos como que o confirmam ao soarem novamente a despeito da morte da órfã. Mas, lendo mais profundamente, a imagem final dos anjos, como algo que desfecha e prevalece, simultaneamente afirma, ao lado do profano, a persistência do sagrado (já indicada na imagem do pó de estrelas), ao qual Trakl nunca renuncia. O poeta obtém aqui a síntese e o paradoxo entre sagrado e profano ao fundi-los em uma unidade perfeita, em uma mesma imagem, e todavia em tensão indissolúvel. O efeito é semelhante ao da fusão dos olhos da órfã com o crepúsculo, fusão que só se sustenta enquanto disiunctio mystica. A disiunctio se estabelece propriamente como um corte na unio, que subsiste irrealizável.

"De Profundis" foi escrito em fins de 1912, quase dois anos antes de estourar a guerra. Mas sob nenhum aspecto seu cenário é menos desolador do que aquele em "Grodek", derradeiro poema de Trakl, escrito em 1914, e que retrata a destruição da Grande Guerra.

GRODEK

Am Abend tönen die herbstlichen Wälder

Von tödlichen Waffen, die goldnen Ebenen

Und blauen Seen, darüber die Sonne

Düstrer hinrollt; umfängt die Nacht

Sterbende Krieger, die wilde Klage

Ihrer zerbrochenen Münder.

Doch stille sammelt im Weidengrund

Rotes Gewölk, darin ein zürnender Gott wohnt

Das vergoßne Blut sich, mondne Kühle;

\section{GRODEK}

Ao entardecer ressoam nas florestas outonais

Armas mortíferas, nas planícies douradas

E lagos azuis, por cima o sol

Mais sombrio rola; a noite envolve

Guerreiros em agonia, o lamento selvagem

De suas bocas dilaceradas.

Mas, quietas no fundo dos prados, se avultam

Nuvens vermelhas, onde mora um deus enfurecido,

O sangue vertido, frieza lunar;

\footnotetext{
${ }^{7}$ Cabe mencionar que, tendo como foco neste texto a tensão própria do romantismo tardio de Trakl - expressão que, por dar mais destaque à perda da possibilidade de ser romântico, preferimos a neorromantismo -, deixamos para um futuro desenvolvimento, dada a complexidade nas caracterizações do expressionismo, a tarefa de explorar mais explicitamente a relação entre romantismo e traços expressionistas em Trakl.
}

Pandaemonium, São Paulo, v. 18, n. 25, Jun. /2015, p. 18-36. 
Alle Straßen münden in schwarze Verwesung.

Unter goldnem Gezweig der Nacht und Sternen

Es schwankt der Schwester Schatten durch den

[schweigenden Hain,

Zu grüßen die Geister der Helden, die blutenden

[Häupter;

Und leise tönen im Rohr die dunklen Flöten des

[Herbstes.

O stolzere Trauer! ihr ehernen Altäre

Die heiße Flamme des Geistes nährt heute ein [gewaltiger Schmerz,
Todas as vias desembocam em negra putrefação.

Sob ramagens douradas da noite e estrelas

Oscila a sombra da irmã pelo mudo bosque.

Para saudar os espíritos dos heróis, as cabeças que

[sangram;

E baixinho soam nos juncos as flautas escuras do [outono.

Oh, orgulhoso luto! Vós, altares de bronze,

Uma dor violenta alimenta hoje a chama ardente [do espírito,

Os netos não nascidos.

Die ungebornen Enkel.

(TRAKL 1973: 94-5)

Como observa James Rolleston (2005: 187-188), o poema inicia como que 'de dentro' da natureza: é das florestas que soam as armas mortíferas; o verbo tönen, inclusive, é usado por Trakl como transitivo indireto com complemento circunstancial - die Wälder tönen von tödlichen Waffen..., literalmente "as florestas ressoam de armas mortíferas..." -, gerando a impressão de que são as próprias florestas que soam, como se as armas mortíferas lhes pertencessem tal como folhas ou pássaros. Assim como em "De Profundis" e na lírica de Trakl de modo geral, a fusão do mundo humano com a natureza possui aqui um sentido negativo e sombrio: a guerra irrompe da floresta, das entranhas da natureza, na medida em que é animalesca, e o homem um ser selvagem. Ainda que em seguida também surjam imagens da natureza em um sentido mais positivo, até mesmo romantizado e sublime - as planícies douradas e os lagos azuis -, essa ambiência romântica só aparece para ser maculada/profanada pelo horror, pois também nelas ressoam as armas mortais. Um tom escatológico se faz sentir quando sobrevém a imagem (recorrente em Trakl) do "sol que rola sombrio pela planície" - "mais sombrio", indicando seu movimento de ocaso, a queda do entardecer para a noite. Nas palavras de ROLLESTON (2005: 188), "esse derradeiro levante dionisíaco funde o humano com o cosmos em voluntária destruição": é uma fusão maligna, em que o mundo está tomado pelo mal, e o mal é a própria guerra. Até aqui no poema, o homem, enquanto combatente da guerra, é completamente reduzido a essa condição: "suas bocas dilaceradas", sua voz humana reduzida ao "lamento selvagem". E se os guerreiros são envolvidos pela noite, essa envolvência nada possui de terna, mas apenas sela e confirma a destruição que fora anunciada e levada a cabo no entardecer (em uma estrutura narrativa muito semelhante, nesse sentido, à que vimos em "De Profundis"). 
Ao começar com doch, a sentença seguinte - doch stille..., "mas, quietas..." - indica o contraste entre o alarido das armas e o lamento dos soldados, de um lado, e, de outro, o silêncio em que "as nuvens vermelhas se avultam...” Todavia, essa quietude não se contrapõe em espírito aos versos anteriores, pois é o mesmo mal que irrompeu da floresta o que aqui, silenciosamente, se ajunta na forma de nuvens vermelhas "no fundo dos prados", "onde mora um deus enfurecido". A quietude pode ser entendida aqui de forma semelhante ao "silêncio de Deus" em "De Profundis", como um consentimento tácito à invasão do mal por parte desse Deus em silêncio. Entretanto, aqui Deus surge mais como uma figura positiva do mal: ele habita, enfurecido, as nuvens vermelhas, e se parece com um mal sorrateiro que se infiltra no mundo, onipresente e onipotente. A fusão maligna do mundo humano com essa presença cósmica do mal se mostra na aposição de "nuvens vermelhas" e "o sangue vertido", como se o sangue derramado na Terra se absorvesse nas nuvens do céu, vermelhas porque embebidas de sangue, ou como se um espelhasse o outro. Já a imagem da "frieza lunar" surge um tanto enigmática como aposto de "nuvens vermelhas" e "sangue vertido", pois, ao contrário destes, não sugere movimento e fúria, e sim parada e em certo sentido apaziguamento. Talvez a frieza lunar se refira ao advento da noite como conclusão do movimento cósmico de destruição e derramamento de sangue, como a face obscura e fria do mal após sua explosão de fúria. Em todo caso, a sensação de uma presença ubíqua - e portanto incontornável - do mal, é confirmada pela imagem que soa como a derradeira conclusão do combate e ponto central de todo o poema: “Todas as vias desembocam em negra putrefação". Não há como escapar ao mal; por onde quer que se vá, é ele o destino voraginoso que atrai e devora todos os caminhos.

No verso seguinte, é introduzida uma imagem aparentemente redentora e apaziguante: "Sob ramagens douradas da noite e estrelas/ Oscila a sombra da irmã pelo mudo bosque./ Para saudar os espíritos dos heróis, as cabeças que sangram”. A irmã (em possível referência à irmã de Trakl), surge como algo espiritual e elevado, cingida por ramagens douradas da noite e por estrelas, e vem para saudar algo de também elevado: os "espíritos dos heróis". Contudo, o aposto a "os heróis" quebra completamente a imagem espiritual, romântica e sagrada: "as cabeças que sangram". O espírito se reduz a corpo, e o corpo a putrefação. Vale observar, porém, que já na imagem da "sombra da irmã oscilando pelo mudo bosque" soa talvez algo de um mau presságio, como um fantasma oscilante no mundo das trevas. Há algo de atormentado em uma sombra oscilante. "E baixinho soam nos juncos as flautas escuras do outono." Novamente o silêncio permeando todo o cenário, permitindo ouvir as flautas que soam baixinho. Elas soam nos juncos, plantas pantanosas, e são as flautas escuras do outono, a estação da queda. Esse verso, como no final de "De Profundis", também tem algo de um 
consentimento cósmico com a fatalidade dos eventos ocorridos: a natureza parece aqui ao mesmo tempo lamentar esses eventos e coroá-los com seu canto, como se tudo pertencesse a um movimento necessário.

“Oh, orgulhoso luto! Vós, altares de bronze,/ Uma dor violenta alimenta hoje a chama ardente do espírito,/ Os netos não nascidos." Essa conclusão não deixa dúvidas sobre a concepção trakliana de um predomínio do mal. Mas aqui não é apenas o desejo de pureza, beleza e bondade que o mal desfaz com sua força maior, mas sim, sobretudo, a suntuosidade humanamente construída para justificar o injustificável: o luto orgulhoso, os altares de bronze erigidos em memória de idealizados heróis - tudo isso, no fundo, é apenas mais uma expressão, uma confirmação do impulso que conduz os homens à destruição. O que prevalece no fim é a potência da morte, infinitamente maior do que todo esse orgulho: os netos dos guerreiros nunca irão nascer. A imagem final é conclusiva, incontornável, irredimível; em um sentido mais amplo, sugere que a guerra matou a vida, a própria possibilidade de continuação da humanidade.

Tal impossibilidade de continuar surge também no poema "Lamento", penúltimo escrito por Trakl. E, ainda que "Grodek" tenha sido seu derradeiro poema, é em "Lamento" que podemos ouvir uma nítida despedida.

KLAGE

Schlaf und Tod, die düstern Adler

Umrauschen nachtlang dieses Haupt:

Des Menschen goldnes Bildnis

Verschlänge die eisige Woge

Der Ewigkeit. An schaurigen Riffen

Zerschellt der purpurne Leib

Und es klagt die dunkle Stimme

Über dem Meer.

Schwester stürmischer Schwermut

Sieh ein ängstlicher Kahn versinkt

Unter Sternen,

Dem schweigenden Antlitz der Nacht.

\section{LAMENTO}

Sono e morte, as sombrias águias

Rondam noite adentro esta cabeça:

A imagem dourada do homem

Tragada pela gélida onda

Da eternidade. O corpo purpúreo arrebenta

Em abomináveis recifes

E a voz escura lamenta

Sobre o mar.

Irmã de tempestuosa melancolia

Vê, um barco temeroso afunda

Sob estrelas

E a muda face da noite.

(TRAKL 1973: 94) 
Sono e morte: a isso se reduziu o universo e a existência para Trakl. Eles parecem ser quase evocados como um doloroso desejo, a "nostalgia da morte" (Sehnsucht nach dem Tode), mas sem a tonalidade romântica em que a morte é pressentida como uma fusão com o todo, e sim enquanto queda absoluta, único destino possível a uma existência à qual é vedada qualquer salvação. Nesse caso, a nostalgia da morte nada mais é que o reconhecimento de um destino inelutável: "Sono e morte", ao mesmo tempo uma evocação e um lamento. As "sombrias águias" que "rondam noite adentro esta cabeça" - "esta" referindo-se à cabeça do eu lírico talvez sejam as aves de rapina que o rondam para tomar-lhe a vida. Embora a águia seja uma figura de grande complexidade simbólica, podendo conotar aspectos positivos e negativos (CHEVALIER \& GHEERBRANT 2006: 22-26), no poema de Trakl o que prevalece certamente é seu "aspecto noturno maléfico ou desastroso... a perversão de sua força" (CHEVALIER \& GHEERBRANT 2006: 25), o seu caráter de "rapinante cruel que rouba com violência" e “carrega as vítimas com suas garras para conduzi-las a lugares de onde não podem escapar" (Chevalier \& GheERbrant 2006: 26) - aqui, o reino de Sono e Morte. Mais um elemento suporta essa leitura: o verbo umrauschen, aqui traduzido por "rondar", significa mais exatamente "farfalhar em volta de", gerando a sensação de uma cabeça verdadeiramente atormentada pelas águias noite adentro, como por algo maligno prestes a acontecer.

Como indicado pelo uso de dois pontos entre o segundo e o terceiro versos, este introduz a derradeira explicação dos anteriores: "a imagem dourada do homem" sendo "tragada pela gélida onda da eternidade". A palavra usada por Trakl em "a imagem dourada do homem" é Bildnis, que comumente possui o sentido de "efígie", uma imagem construída pelo homem, como a das cabeças em moedas. Nesse sentido, poder-se-ia interpretar "A imagem dourada do homem/ Tragada pela gélida onda/ Da eternidade" como o aniquilamento da imagem de si próprio construída pelo homem. Mas, mais forte que isso, a referência parece ser a Gênesis, 1: 27: "E Deus criou o homem à sua imagem". Mais do que uma imagem de si construída pelo homem, tratar-se-ia de uma determinação que transcende o homem, seja porque algo muito acima dele assim o determinou, seja porque tal imagem é a aspiração (malograda) do homem. As coisas se confundem: desfaz-se a aspiração do homem a ser imagem de um Ser Perfeito, ou o que se desfaz é a determinação, dada por esse Ser, de que o homem fosse Sua imagem (Deus desiste do homem). A segunda leitura funciona como uma metáfora da primeira. Em todo caso, mesmo que a intenção nesse poema seja conferir uma existência a Deus, vale observar que também ela é finita e impotente: maior que ela é a "gélida onda da eternidade", que engole a "imagem dourada do homem" à semelhança de Deus, seja esta uma mera aspiração do homem ou uma determinação divina. A única coisa 
que aqui se eterniza é o mal. Assim, enquanto "a imagem dourada" do homem se desfaz, e o seu "corpo purpúreo", carnal e sem alma, "arrebenta em abomináveis recifes", acima/em torno a essa perda a "voz escura lamenta sobre o mar" - voz que pode ser a daquele Deus cujo intuito se desfaz, mas também a de Trakl, no lamento da sua própria tristeza infinita. Podemos ainda lembrar que o título deste poema, assim como várias das formas recorrentes na lírica de Trakl, remete à linguagem da tradição cristã: lamentações, salmos (dentre os quais o aqui citado De Profundis), cânticos..., o que faz contrastar ainda mais o dilema existencial cantado pelo poeta, na medida em que ele se vale de formas que supõem um fundamento e um endereçamento que não mais se sustentam em um mundo sem Deus.

Os próximos versos parecem conter um grito angustiado de despedida. A irmã de Trakl, talvez a figura que lhe fosse mais próxima e querida, é invocada: "Irmã de tempestuosa melancolia/ Vê, um barco temeroso afunda/ Sob estrelas/ E a muda face da noite.” Irmã de

melancolia, irmã em melancolia, como quando se diz que alguém é um “irmão de espírito". É àquela que talvez mais profundamente compartilhou sua melancolia, tonalidade afetiva predominante de sua alma, que o poeta pede que veja o que lhe acontece: em um barco temeroso, afunda - sob estrelas, sob os olhos e o mudo consentimento da Noite.

\section{Considerações finais}

Mediante uma contextualização da poesia de Trakl em sua relação com o romantismo e, em seguida, a análise dos poemas "De Profundis", "Grodek" e "Lamento", buscamos indicar que a existência vivida e o mundo vislumbrado por Trakl não correspondem e não sustentam justamente o que se exprime como a sua grande nostalgia: um romântico desejo de beleza, pureza e bondade. Ao usar com constância os mesmos recursos expressivos, a poesia trakliana transmite uma sensação de mundo sempre tingida pela mesma tonalidade afetiva: a dor inextirpável de aquela nostalgia ser fadada ao fracasso, refutada pelo mal inerente ao mundo. Dentre esses recursos - cuja riqueza e integração não seria possível explorar em um trabalho tão breve - tentamos aqui destacar, sobretudo: a lenta sucessão de imagens suscitando uma atmosfera de fatalidade malévola; elementos de mau presságio que o eu lírico percebe/imagina em movimentos da natureza; o avanço de imagens do mal sobre imagens de pureza; uma indiferença, senão uma espécie de consentimento, por parte do próprio universo diante do mal; a sensação de que sujeito lírico e mundo compartilham uma mesma 
subjetividade, o que no entanto se dá ao modo de uma disjunção, e não de uma união mística. Todos esses elementos se combinam sinergicamente para expressar o tom de angustiada melancolia que permeia os poemas de Trakl como o lamento de uma verdadeira impossibilidade existencial. Assim, não mais uma nostalgia esperançosa, como no romantismo, mas apenas uma nostalgia melancólica é a tonalidade afetiva que acompanha a visão trakliana de um prevalecimento do mal, imposto ao homem como condição perene. Sua poesia se faz como um canto do desejo impossível, e como lamento do que é: embora o poeta ainda seja romântico, o mundo já não é romantizável.

A escolha pelos poemas "De Profundis", "Grodek" e "Lamento" foi feita também com o intuito de explorar a relação entre a experiência de prevalecimento do mal (e nostalgia do bem irrecuperável ou impossível) e a experiência da Guerra, na medida em que os dois poemas escritos logo após a batalha de Grodek - "Grodek" e "Lamento" - compartilham com um poema anterior à irrupção da Guerra - "De Profundis" - uma mesma atmosfera, uma mesma tonalidade afetiva fundamental e um uso semelhante daqueles recursos usados com constância por Trakl. Nesse sentido, procuramos explicitar, por exemplo, que o modo e a atmosfera em que a guerra surge no poema "Grodek" é equiparável ao modo e a atmosfera em que a história da órfã se desenrola em "De Profundis". Ambos os poemas narram afirmações do mal, enquanto o tom testemunhal de Trakl é sempre aquele do lamento, de quem deseja dizer luz, mas é obrigado a dizer trevas: em "De Profundis", "Há uma luz, que se apaga na minha boca"; em "Grodek", "Todas as vias desembocam em negra putrefação", no que se pode ler a inclusão do sujeito lírico: também sua voz termina na (des)articulação do mal. Assim, se nunca se identifica com o mal, mas ao mesmo tempo não pode furtar-se ao destino de pronunciá-lo e, nesse sentido, mediá-lo, essa voz não pode senão exprimir um pesaroso lamento. Como não pensar na significância do título de seu penúltimo poema, "Lamento"? Como não pensar que os versos "a imagem dourada do homem/ Tragada pela gélida onda/ Da eternidade..." não concluem a derrocada da imagem do homem como um ser espiritual, coroamento da criação divina, pois à guerra tal imagem não poderia sobreviver? É significativo que a palavra lamento intitule um poema escrito no calor da experiência de Trakl na guerra ao mesmo tempo em que funciona como uma conclusão para toda sua obra, que muito antes desse momento decisivo já se encaminhava para semelhante fim. A leitura comparada desses três poemas ressalta portanto não apenas sua unidade formal, mas a profunda identidade de uma mesma concepção, um mesmo olhar para o mundo, uma mesma sensibilidade, em que a Guerra, seja porque confirma essa visão, seja porque a alimenta, 
exerce em todo caso o impacto de um processo profundamente internalizado, não o de um evento exterior do qual o sujeito pudesse desligar-se.

Nesse sentido, integram-se a observação de Pellegrini (2009: 10) de que a poesia de Trakl "poderia resumir o sentido exemplar de toda poesia, se é o fim de toda poesia incitarnos a recuperar esse mundo ideal a que aspira o homem, e se é a um só tempo denúncia e recusa do mundo falso, inautêntico que se nos oferece" e a de STAROBINSKI (1999: 9) a respeito das poesias que vigorosamente testemunham a Guerra:

Perante certos acontecimentos graves e absolutos, o testemunho, nascido em suas profundezas, profere o canto: o grito que se esforça pela pureza. Face ao destino, um ato libertador se cumpre, - palavra que exprime o terror e a piedade diante do mal, que denuncia a cegueira passional, palavra que conduz a desgraça à luz gloriosa que nada pode macular.

É preciso dizer que supor nessa resistência romântica de Trakl ao mal um simples maniqueísmo seria grande injustiça ao poeta, para quem a bondade e a pureza são olhadas, por assim dizer, de frente, em sua impotência. Mas não só isso: o homem, para Trakl, é um ser fadado à destruição e incontornavelmente desgraçado não apenas por ser abandonado (por um Deus inexistente ou indiferente) ao mal, mas também, e talvez sobretudo, porque ele próprio é perpetrador do mal. Como bem observa BARRENTO (1992: 11), Trakl "nunca coloca a questão religiosa para encontrar qualquer forma de salvação, mas sempre, e apenas, para confirmar uma culpa". Por um lado, ele verbaliza o mal, reconhecendo a pureza e a bondade como estrangeiras sem lugar no mundo e impotentes diante da corrupção. Por outro, ele justamente o recusa, e afirma a pureza e a bondade, ainda que em uma condição de impotência. Seria essa a sua impossibilidade existencial, capaz de realizar na poesia aquele sentido especial que, segundo STAROBINSKI (1999: 10), um testemunho pode assumir: "o sentido sagrado de um martírio". Não se permitindo furtar-se ao inferno, Trakl tampouco se submeteu a ele.

\section{Referências bibliográficas}

BARRENTO, João, 'Georg Trakl: o mosaico da morte', in TRAKL, Georg. Outono Transfigurado. orto: Assírio e Alvim, 1992.

CARone, Modesto, Metáfora e Montagem. São Paulo: Perspectiva, 1974.

Cavalcanti, Claudia. 'Emergir das Profundezas de G. T.: uma tentativa', in TrakL, Georg. De Profundis. São Paulo: Iluminuras, 2010.

Chevalier, Jean; GHeERBRAnt, Alain, Dicionário de Símbolos. Rio de Janeiro: José Olympio, 1989. 
HAMMER, Anette, Lyrikinterpretation und Intertexualität. Studie zu Georg Trakls Gedichten "Psalm I" und "De Profundis II". Würzburg: Könnigshausen \& Neumann, 2006.

KLEEFELD, Gunther, Das Gedicht als Sühne: Georg Trakls Dichtung und Krankheit. Eine Psychoanalytische Studie. Tübingen: Niemeyer, 1985.

Matvejevitc, Pedrag, Pour une poétique de l'événement. Paris: 10/18, 1979.

Novalis. Hinos à Noite, Prefácio e tradução Fiama Hasse Pais Brandão. Lisboa: Assírio \& Alvim, 1998.

PellegrinI, Aldo. 'Introducción a la poesía de Trakl', in TrAKL, Poemas. Buenos Aires: Corregidor, 2009.

RIMBAUD, Arthur, Les Illuminations, Une Saison en Enfer. Paris: León Vanier, 1892.

Rolleston, James, 'Choric Consciousness in Expressionist Poetry', in A Companion to the Literature of German Expressionism. Ed. Neil H. Donahue. New York: Camden House, 2005.

SANTos, Manuela Delfim, Morte, Amor e Poesia: o Romantismo em Novalis. Edição original na Revista da Faculdade de Letras de Lisboa, 1947, disponível em: http://www.delfimsantos.net/manuela/Novalis.htm. Acesso em: 7 out. 2014.

SEligmanN-Silva, Márcio. 'Poemas nascidos entre as sombras'. Disponível em: http://www.estadao.com.br/noticias/impresso,poemas-nascidos-entre-assombras,675486,0.htm. Acesso em: 9 jan. 2015.

StAROBInSKi, Jean, La Poésie et la Guerre. Genéve: Zoè, 1999.

TraKL, Georg, De Profundis. Tradução e posfácio de Claudia Cavalcanti. São Paulo: Iluminuras, 2010.

. Das Dichterische Werk auf Grund der historisch-kritischen Ausgabe von Walther Killy und Hans Szklenar. München: Deutscher Taschenbuch, 1973.

. Outono Transfigurado, Tradução e prefácio de João Barrento. Porto: Assírio e Alvim, 1992.

. Poemas, Tradução, prólogo e notas de Aldo Pellegrini. Buenos Aires: Corregidor, 2009.

Recebido em 24/02/2015

Aceito em 13/04/2015 